\title{
Pharmacognostic Studies of the Leaves and Fructus of Arctium Iappa L. (Asteraceae Bercht. \& J. Presl)
}

\author{
Kolomiets Natalia Eduardovna ${ }^{1,2, *}$, Korolev Stepan Alexandrovich', Isaykina Nadezhda Valentinovna', \\ Abramets Natalia Yurievna ${ }^{1}$, Kudryavtseva Darya Vladimirovna ${ }^{1}$, Boev Roman Sergeevich ${ }^{3}$, Zhalnina Ludmila \\ Vladimirovna', Ali Abdujalil Kaid Hasan', Bondarchuk Ruslan Anatolevich ${ }^{4}$
}

\begin{abstract}
Kolomiets Natalia Eduardovna ${ }^{1,2, *}$, Korolev Stepan Alexandrovich', Isaykina Nadezhda Valentinovna', Abramets Natalia Yurievna', Kudryavtseva Darya Vladimirovna ${ }^{1}$, Boev Roman Sergeevich ${ }^{3}$, Zhalnina Ludmila Vladimirovna' ${ }^{1}$, Ali Abdujalil Kaid Hasan', Bondarchuk Ruslan Anatolevich ${ }^{4}$
\end{abstract}

'Department of Pharmaceutical Analysis, Siberian State Medical University, Tomsk, RUSSIA.

${ }^{2}$ Department of Pharmacy, Kemerovo State Medical University, Kemerovo, RUSSIA. "LLC "Visterra», Barnaul, RUSSIA.

${ }^{4}$ Office of the State Employment Service in the Kirov region, Kirov, RUSSIA.

\section{Correspondence}

\section{Kolomiets Natalia Eduardovna}

Department of Pharmaceutical Analysis, Siberian State Medical University, Tomsk; Department of Pharmacy, Kemerovo State Medical University, Kemerovo, RUSSIA.

E-mail: borkol47@mail.ru

History

- Submission Date: 05-10-2021;

- Review completed: 28-10-2021;

- Accepted Date: 09-11-2021.

DOI : 10.5530/pj.2021.13.224

Article Available online

http://www.phcogj.com/v13/i6

\section{Copyright}

(C) 2021 Phcogj.Com. This is an open access article distributed under the term of the Creative Commons Attribution 4.0 International license.

\begin{abstract}
Introduction: The state quality assurance system ensures the confidence of consumers that the product meets its quality requirements. In this study, pharmacognostic standards of the leaves and fructus of burdock are specified for the first time. Methods: Microscopic analysis was carried out by using the microscope Carl Zeiss. The UV spectrum were measured on an SF-2000 spectrophotometer. Results: Macroscopically, the leaves are heart-shaped, broad-heart-ovate-shaped with a spaced emarginatedserrate or whole edge, with a wide, wedge-shaped, rounded, uneven base, acute apex, green on the outer surface, grayish slightly pubescent on the inner surface. The fructus are obovate or wedge-compressed, slightly curved, the color is brown/black with spots, or variegated with black spots on a gray background The microscopic examination of the leaves revealed the presence of epidermis, large submerged and non-submerged stomata of the anomocytic type, 2 types of simple unbranched multi-cellular and glandular capitate trichomes; essential oil glands. Microscopic examination of the leaf petiole revealed the presence of 2 types of simple multi-cellular trichomes, epidermis, angular collenchyma, bicollateral bundles, parenchyma. The stomatal index value is $8.28 \pm 0.81$ per $1 \mathrm{~cm}^{2}$. The microscopy of the fructus revealed the presence of elongated cells of the pericarp epidermis; mesocarp; endocarp; endosperm with aleurone grains and drops of fatty oil. The qualitative phytochemical analysis of revealed the presence of polysaccharides, tannins, flavonoids, terpenoids, saponins, phenolic acids. Conclusion: Physical and chemical parameters (moisture, extractive value, ash content) were also specified. These specific data are important for establishing diagnostic indicators for standardization, identification, preparation of new quality standards.

Key words: Analitical standarts, Arctium lappa L., Fructus, Leaves, Pharmacognostic standarts, Phytochemical analysis.
\end{abstract}

\section{INTRODUCTION}

Arctium lappa $\mathrm{L}$. is one of the six species of the genus Arctium L., of the family Asteraceae Bercht. \& J.Presl widely distributed as a weed in Europe, the USA, Uruguay, Argentina, the Himalayas, China, Japan, the European part of Russia, the Caucasus, Western Siberia, and the Far East. ${ }^{1,2}$

Burdock has been used in folk medicine in different countries since ancient times. Burdock oil was used to strengthen and nourish hair, as a remedy for lice, rashes, lichen, trophic ulcers. Fresh burdock leaves were used for burns, rashes, itching, eczema, ulcers and dermatitis, mouth and eyes mold lesions. Juice and decoctions were used for gout, to stimulate metabolism, treat arthritis and arthrosis, articular rheumatism, sciatica, bad breath, urolithiasis, stomach ulcer. Antibacterial properties of big burdock were used for sore throats, syphilis, inflammation of the mucous membranes of the genitals, initial forms of upper respiratory tract diseases, inflammation of the mucous membranes of the mouth, gums, throat, and, due to their anti-parasitic effect, they are used for intestinal worms..$^{3-7}$ Folk medicine has accumulated the experience in treatment of prostate adenoma and other oncological diseases with fresh juice, galenic preparations of burdock roots, leaves, inflorescences. ${ }^{8,9}$ In China, the seeds and roots of big burdock are used for insect and venomous snake bites, edema, hemorrhages, boils, as well as cholagogic, diuretic treatments. ${ }^{10}$

In Russian official medicine only three types of burdock roots are used - Arctium lappa L., Arctium tomentosum Mill., Arctium minus Mill. ${ }^{11}$ In Japanese official medicine the fructus of Arctium lappa $\mathrm{L}$ are used. ${ }^{12}$ Fresh roots of Arctium lappa L. harvested in the autumn of the first year or in the spring of the second year before florification are used to obtain pharmacopoeial homeopathic preparations. ${ }^{13}$

In several in vitro, in vivo studies and clinical trials on volunteers antimicrobial, hepatoprotective, antioxidant, antimutagenic, anti-inflammatory, immunostimulating, antitumor properties of extracts, aqueous extraction, essential oil, resinous substances and root juice were proven; anti-microbial, anti-viral, anti-oxidant, anti-ulcer, anti-inflammatory potential of extracts and leaf juice was shown. ${ }^{14-32}$

Burdock roots have a promising anti-diabetic effect which is manifested in the improvement of glucose homeostasis and a decrease in insulin resistance. ${ }^{33}$ Big burdock root inulin is used for the prevention and treatment of diabetes mellitus, normalization of pancreatic function. ${ }^{34-37}$

Water and ethanol fructus extracts reduce the production of histamine and pro-inflammatory 
cytokines; ethanol extract has pronounced in vitro schistosomicidal, antiherpetic, and anti-allergic effects. ${ }^{38-43}$ Some fructus compounds have an anti-inflammatory and powerful inhibitory effect on tumor growth ${ }^{44-51}$ Randomized, placebo, as well as controlled clinical studies, have shown that burdock fructus mucus has a therapeutic effect on dryness, itching, and skin burns. ${ }^{52,53}$

The data presented in the topic-related literature proves the prospects of the Arctium lappa L. fructus and leaves use for medical purposes. Therefore, it is necessary to establish microscopic, macroscopic and analytical standards in order to avoid falsification. The purpose of the given research is to study the pharmacognostic standards of fructus and leaves to obtain their diagnostic features, thereby establishing diagnostic indices that will be useful in assessing purity, quality, safety and standardization of samples of medicinal raw materials.

\section{MATERIALS AND METHODS}

\section{Collection, identification, and preparation of plant materials}

The target of the research was big burdock leaves of the first and second year of vegetation harvested in the middle of the growing season, fructus collected in autumn during the fruiting season of 2019-2021 from wild and cultivated Arctium lappa L. Wild big burdock was harvested on the territory of Tomsk district of Tomsk region (Russia) (Figure 1), cultivated big burdock was collected at the production site of LLC "Wisterra" (Altai Krai, Russia) (Figure 2).

During plant raw materials' harvesting, areas with similar conditions of shading/illumination and moisture were selected. Harvesting was carried out during the same part of the day. The authenticity of samples was proven by the Department of Pharmaceutical Analysis of the Siberian State Medical University, Tomsk, Russia.

Fresh leaves were dried to an air-dry state in the open air in the shade. The dried raw material was crushed to a particle size of 3-5 mm, packed and used later for pharmacognostic research.

\section{Photomicrographs}

Photomicrographs with different magnifications were made using a "Carl Zeiss" microscope (Germany) and a "Canon" camera (Japan). For normal observations, a light background was used. Polarized light was used to study lignified cells and starch grains. Descriptive terms of anatomical features are given in accordance with the individual articles of the State Pharmacopoeia of the Russian Federation. ${ }^{11}$

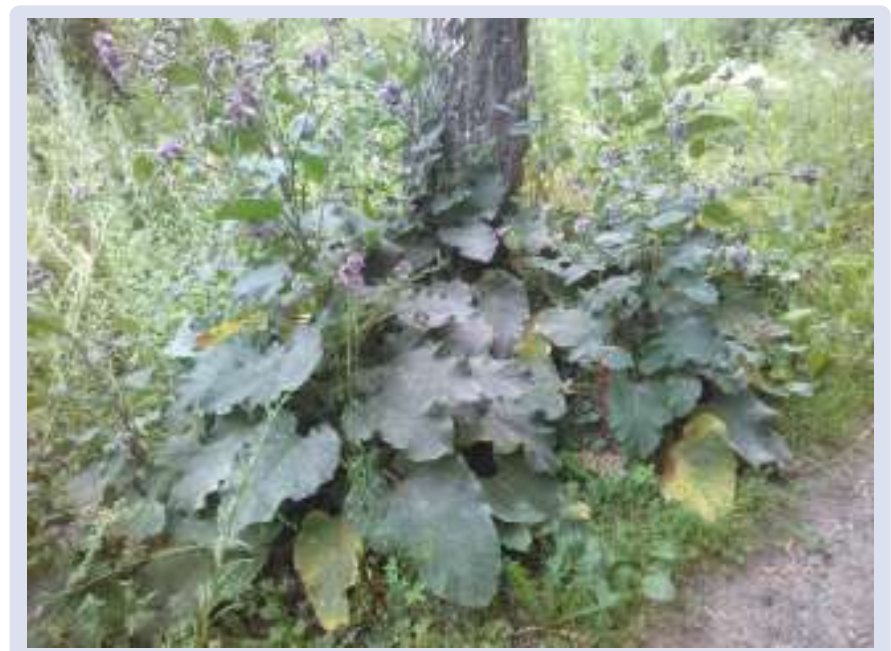

Figure 1: Photograph of Arctuim lappa growing in its natural habitat (Tomsk region, Russia).

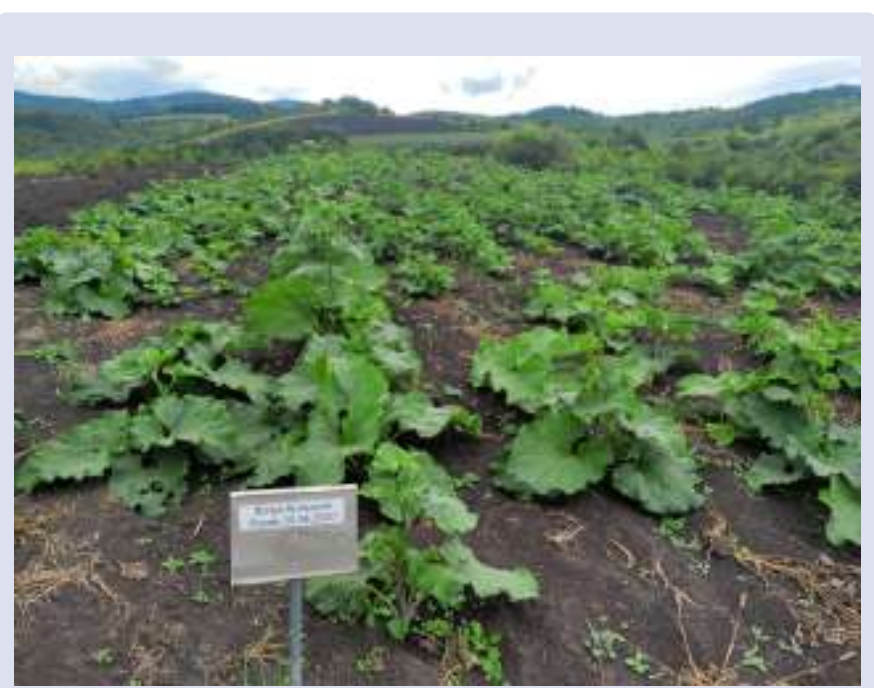

Figure 2: Photograph of Arctuim lappa cultivated (Altai region, Russia).

\section{EXTRACTION}

\section{Fractions and extract}

About $50 \mathrm{~g}$ of dried leaves, fructus was extracted with various solvents with increasing polarity. The used solvents were chloroform, ethyl acetate, ethanol, and distilled water $(350 \mathrm{ml}$ each separately for 30 minutes). The extracts were concentrated on a rotary evaporator under reduced pressure at $35-40^{\circ} \mathrm{C}$ and stored at $4^{\circ} \mathrm{C}$ in a refrigerator until further use.

\section{Phytochemical analysis}

Preliminary phytochemical analysis was performed in different fractions and extracts to study the class of contained substances. Standard methods of the State Pharmacopoeia of the Russian Federation, as well as methods widely used in pharmacognosy and phytochemistry were used for phytochemical analysis. ${ }^{11,54}$

\section{Histochemical reactions}

To confirm the presence of various groups of substances, the methods of the State Pharmacopoeia of the Russian Federation and other methods adopted in pharmacognosy were used..$^{11,54}$

Reactions on the presence of fatty and essential oils were conducted by the colouration with a solution of Sudan III; mucus with a solution of black ink; inulin after addition of alcohol and concentrated sulfuric acid; lignin with aniline sulfate.

\section{UV spectrum}

An extraction using water acidified with hydrochloric acid was obtained to confirm the presence of anthocyanins in the raw material, detected in the epidermis by microscopic examination of leaf petioles. To perform this task, $1.0 \mathrm{~g}$ of crushed raw material was placed in an Erlenmeyer flask with a capacity of $100 \mathrm{ml}$, then $50 \mathrm{ml}$ of purified water containing $1 \%$ hydrochloric acid ( $\mathrm{pH} 2)$ was added. The flask was attached to a reverse refrigerator and heated in a boiling water bath for 30 minutes. After this time, the resulting extract was cooled to room temperature, filtered through a paper filter, and the optical density was measured on an SF-2000 spectrophotometer (OKB Spektr, Russia) in a channel with a layer thickness of $10 \mathrm{~mm}$ in the wavelength range of 500 $540 \mathrm{~nm}$. As a comparison solution the extractant used to obtain the extraction was used. 


\section{PHARMACOGNOSTIC STANDARDIZATION}

\section{Macroscopic examination}

Fresh and dried leaves and fructus were examined using the methods described in the $14^{\text {th }}$ edition of the State Pharmacopoeia of the Russian Federation of the General Pharmacopoeia Monograph (GPM) "Leaves", "Fructus", "Technique of microscopic and micro-chemical research of medicinal plant raw materials and medicinal plant products".

Macroscopic features of leaves, which include color, smell, taste, structure, leaf shape, leaf base and apex, type of leaf edge, presence of petiole, its parameters, type of petiole surface, parametres, leaf trichome and petiole, leaf venation, presence of essential oil glands, hairs were studied and documented.

Macroscopic features of fructus, such as shape, size, surface character, skin features, presence of peduncle, color of the pericarp, smell, taste, color were also studied and documented.

\section{Microscopic examination}

Quantitative microscopy of the leaves

Was carried out according to the standard methods of the European Pharmacopoeia including specification of the stomatal index, number of stomata; ${ }^{55}$ the number of certain types of trichomes was additionally studied.

\section{Qualitative microscopy of the leaves, fructus}

Well-known and described in the topic-related sources techniques of qualitative microscopy were used in this study. ${ }^{11}$

\section{RESULTS}

\section{Phytochemical analysis}

The results of phytochemical screening of biological active substances in the leaves and fructus of burdock are presented in table 1.

\section{Histochemical reactions}

The presence of fatty oil in fructus was discovered by characteristic colouration in orange-yellow colour with a solution of Sudan III, whereas essential oil in leaves - by colouration in orange-yellow color with the same reagent. Essential oil is clearly visible without any dyes in the leaf preparation in the form of light yellow drops; mucus in the leaves is a colorless mass on a black background made visible by the solution of black ink; inulin is present in the form of spherocrystals settling out after the addition of alcohol and concentrated sulfuric acid in leaves petioles; lignin is discovered by yellow colouration reaction with aniline sulfate (sclereids and sclerenchymatous fibers).

\section{UV spectrum}

In the studied region of the spectrum, the acidified aqueous extract of leaf petioles has a maximum at $510 \pm 3 \mathrm{~nm}$ (Figure 3).

\section{Pharmacognostic standardization}

\section{Macroscopic examination}

2. Macroscopic examination of leaves presented in Table 2, fructus in Table 3.

\section{MICROSCOPIC EXAMINATION}

\section{Quantitative microscopy of the leaves}

Considerable pubescence of the lower surface of the leaf did not allow counting the number of stomata and the stomatal index. Therefore, quantitative assessment of these indicators was carried out only for the upper surface of the leaves of the lower, middle and upper tiers. Additionally, the number of glandular capitate trichomes was counted. The data is given in Table 4.

\section{Qualitative microscopy of the leaf and fructus}

\section{Qualitative microscopy of the leaf}

Microscopy of the leaves revealed that they are amphistomatic (stomata are found on the adaxial and abaxial surfaces of the leaf). The stomata are large, oval of anomocytic type. There are also several types of trichomes: simple multicellular unbranched with thin and thick walls, a long sinuous end cell, glandular capitate trichomes with a single-celled rounded or oval head and a multi-cellular leg. Essential oil glands were found on the surface of the leaves.

On the leaves petioles there are only simple multicellular unbranched trichomes with thin and thick walls and a long, sinuous terminal cell.

\section{Traverse section of the leaf petioles and fructus}

Traverse sections of leaves and fructus petioles of big burdock revealed the presence of characteristic microscopic features shown in Figures 4-10.

\section{Analytical standards of leaf and fructus of Arctium lappa}

The analytical standards of the leaf and fructus of Arctium lappa revealed the composition of the total ash, acid insoluble ash, dilute

Table 1: Phytochemical analysis of the Arctium lappa.

\begin{tabular}{|c|c|c|c|c|}
\hline Class of compounds & ETF & EAF & CHF & WE \\
\hline \multicolumn{5}{|c|}{ Leaf ( 1 year of vegetation / 2 years of vegetation) } \\
\hline Flavonoids & $+/++$ & $++/+++$ & $+1+$ & $+/++$ \\
\hline Phenolic acids & $+++/+$ & $++1+$ & $++1+$ & $++/++$ \\
\hline Polysaccharides & $+/++$ & $-1-$ & $-1-$ & $+++/+++$ \\
\hline Tannins & $++1+++$ & $-1-$ & $-1-$ & $++/+++$ \\
\hline Terpenoids & $+1+$ & $+1+$ & $+1+$ & $+1+$ \\
\hline Saponins & $+/++$ & $+1+$ & $+1+$ & $+1+$ \\
\hline \multicolumn{5}{|l|}{ Fructus } \\
\hline Flavonoids & + & - & - & + \\
\hline Phenolic acids & + & - & - & + \\
\hline Polysaccharides & - & - & - & + \\
\hline Tannins & + & - & - & + \\
\hline Terpenoids & - & - & - & - \\
\hline Saponins & + & - & - & + \\
\hline
\end{tabular}

Key: ETF $=$ Ethanol fraction, EAF $=$ Ethyl Acetate fraction, CHF $=$ Chloroform fraction, WE $=$ water extract; $«-»=$ not present, «+» $=$ present, «++» = present in moderately high quantity, «+++»= present in very high quantity. 
Table 2: Macroscopic evaluation of leaf of Arctium lappa.

\begin{tabular}{ll}
\hline Parametres & Observations \\
\hline Colour & Green on the outer surfaces, greyish pubescent on the inner surface \\
Structure and shape of leaf & very large, heart-shaped or broad-heart-ovate \\
Margin of leaf & spaced emarginate -serrate or whole \\
Composition of lamina & Simple \\
Venation & Cirro-reticular \\
Base and top Apex of the leaf & Wide, wedge-shaped, rounded, uneven base, acute apex \\
Size & $0,2-50 \mathrm{~cm}$ long and $0,2-40 \mathrm{~cm}$ wide \\
Presence of a petiole, its size & long petiole $30 \mathrm{~cm}$ and more $(55 \mathrm{~cm})$ \\
Pubescence of leaf and petiole & Dense pubescent on the inner surface of leaf and sparse hairs on the outer surface; pubescent on the \\
Surface of petiole & surface of petiole \\
Odour & Ribbed \\
Taste & Without odour \\
Presence of essential oil glands, trichomes & Bitter
\end{tabular}

Table 3: Macroscopic evaluation and organoleptic properties of fructus of Arctium lappa.

\begin{tabular}{ll}
\hline Parametres & Observations \\
\hline Shape & obovate, wedge-compressed, slightly curved \\
Colour & brown with spots, sometimes black, variegated with black spots on a gray background \\
Odour & Practically odorless \\
Taste & Slightly bitter and oily \\
Size & $4-7 \mathrm{~mm}$ long, $2-3 \mathrm{~mm}$ in width \\
Surface & matte,fine- wrinkled \\
Presence of a peduncle & In the center of the base of the fruit \\
Number of seeds & One seed, consisting of two large cotyledons, fused with the pericarp
\end{tabular}

\section{Table 4: Quantitative microscopic evaluation of leaf of Arctium lappa.}

\begin{tabular}{llc}
\hline Parametres & & Values \\
Stomatal number & Upper epidermis & $2.91 \pm 0.29$ \\
Stomatal index & Upper epidermis & $8.28 \pm 0.81$ \\
Capitate glandular trichomes & Upper epidermis & $2.36 \pm 0.2$ \\
& Lower epidermis & $1.96 \pm 0.2$
\end{tabular}

Key: The values obtained are the mean for upper, lower and middle leaves.

Table 5: Analytical standards of leaf, fructus of Arctium lappa.

\begin{tabular}{lcc}
\hline \multirow{2}{*}{ Parametres } & \multicolumn{2}{c}{$\%$ w/w composition } \\
\cline { 2 - 3 } Total ash & not more than $14 \%$ & not more than $7 \%$ \\
Acid insoluble ash & not more than $5 \%$ & not more than $1 \%$ \\
Water soluble extractive value & not less than $20 \%$ & - \\
$\begin{array}{l}\text { Dilute ethanol soluble extractive value } \\
\text { Moisture }\end{array}$ & - & not less than $15 \%$ \\
not more than $13 \%$ & not more than $12 \%$
\end{tabular}

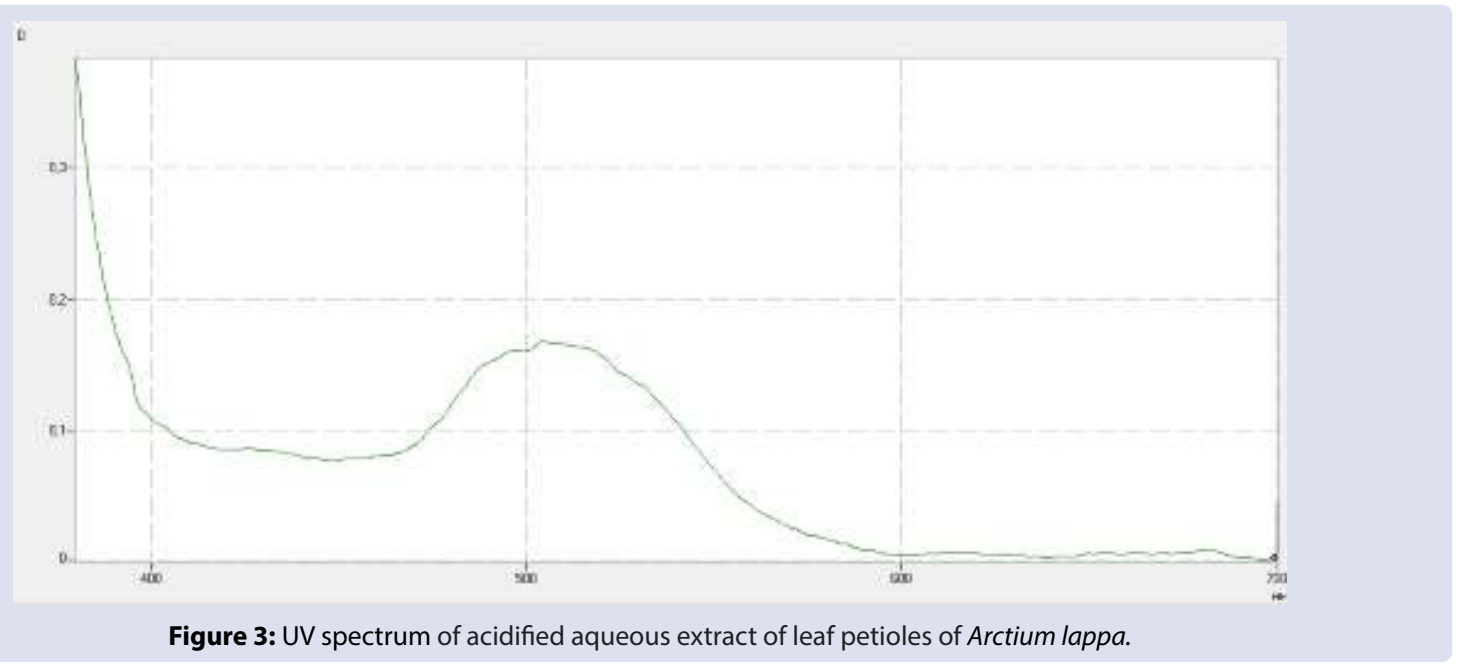




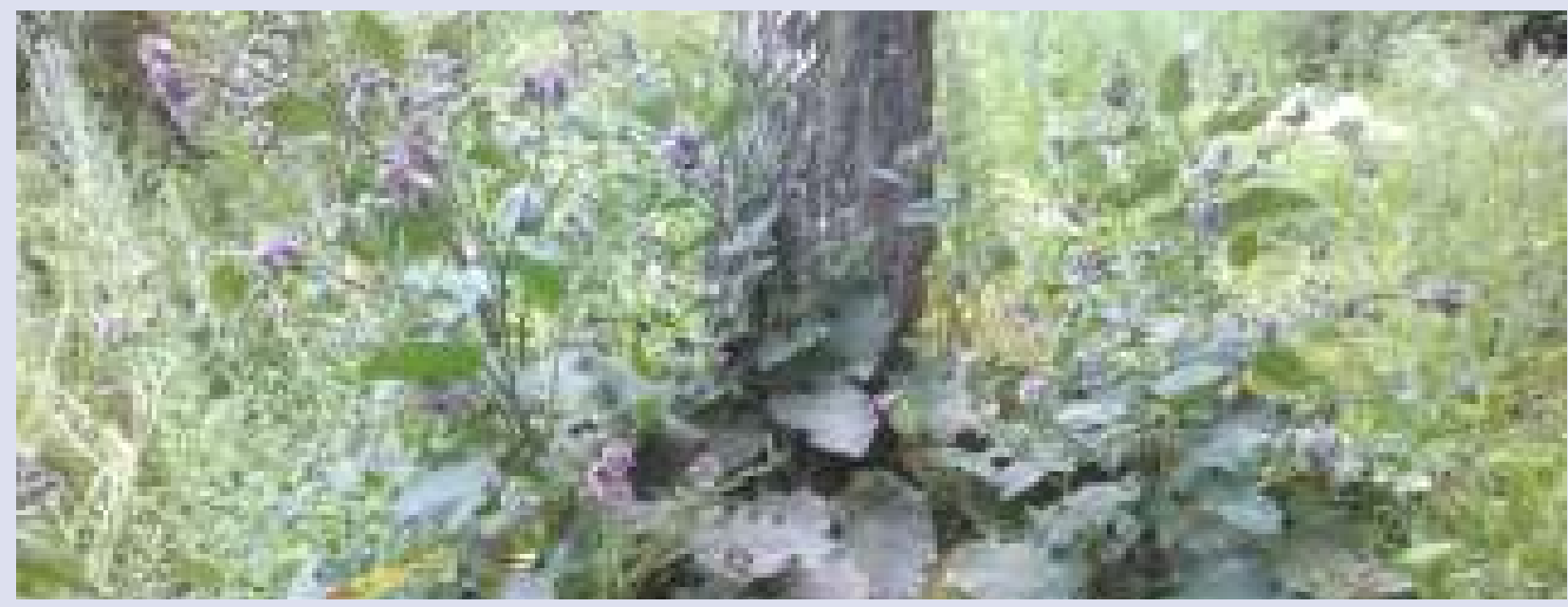

Figure 4: Photomicrograph of leaf of Arctium lappa. Epidermis with straight walls (A); highly sinuous walls (B), stomata of the anomocytic type.

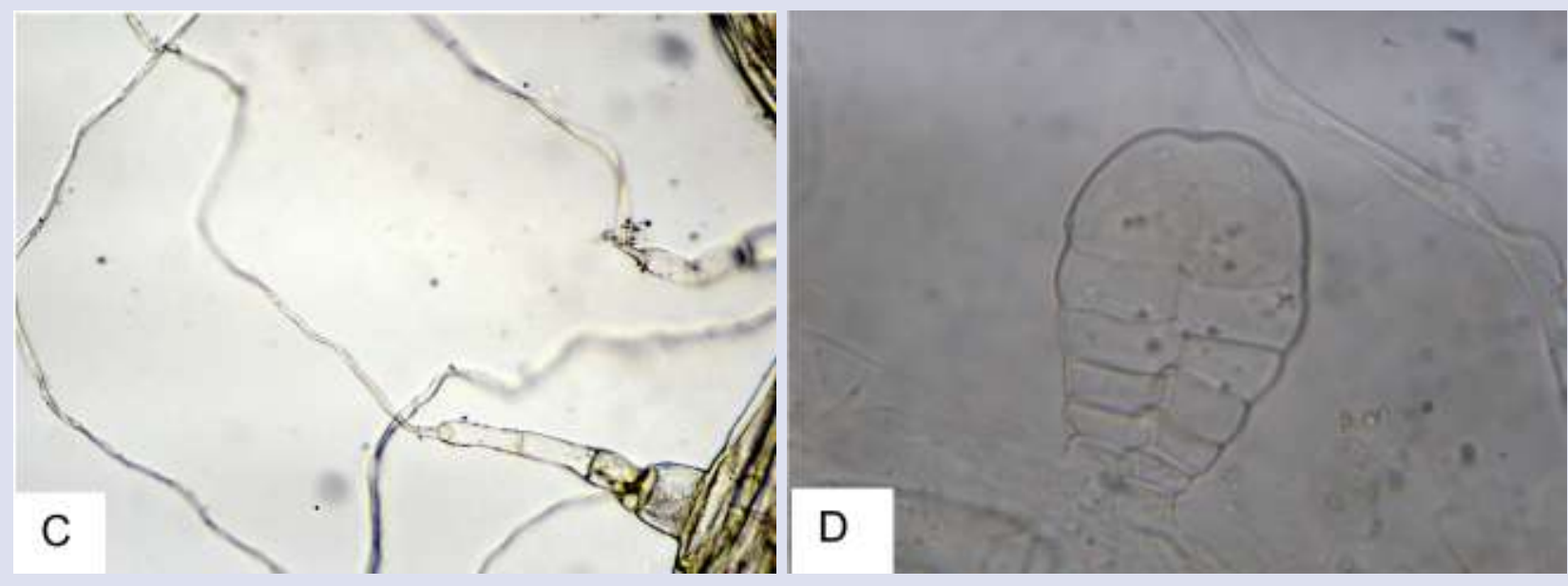

Figure 5: Photomicrograph of leaf of Arctium lappa. Simple multicellular trichome (C); essential oil gland (D).
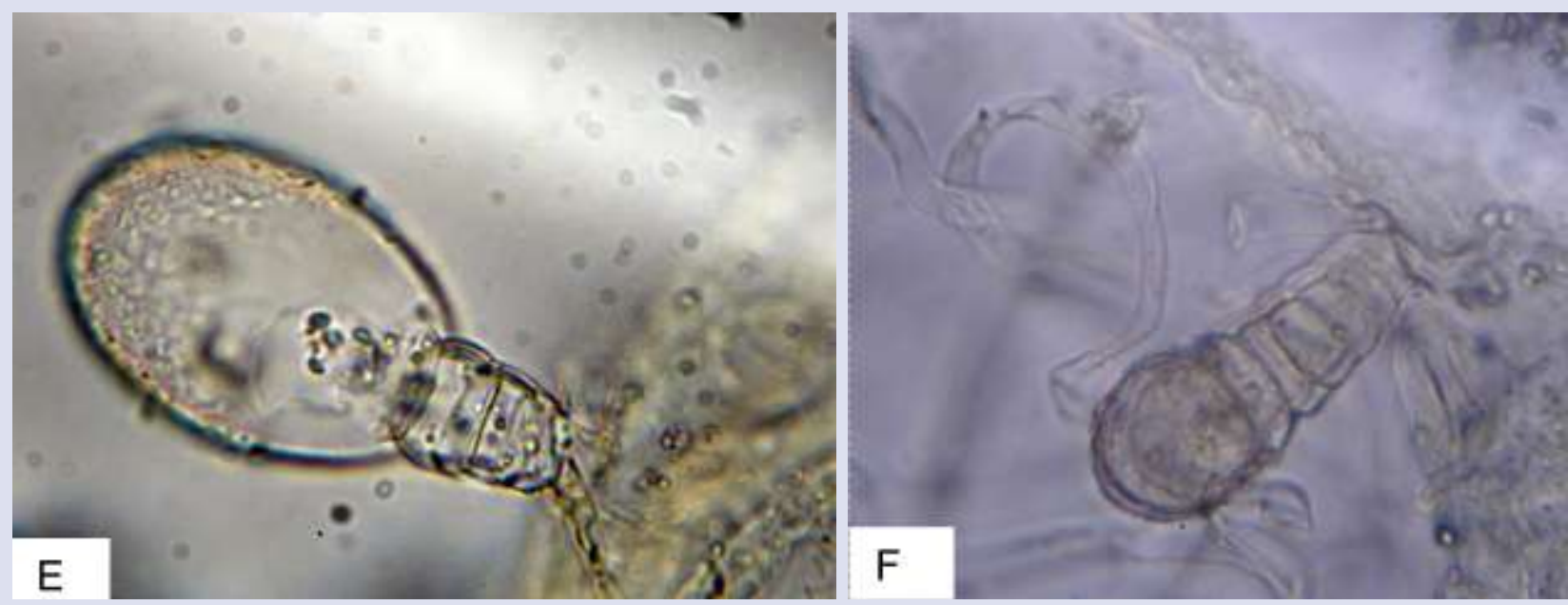

Figure 6: Photomicrograph of leaf of Arctium lappa. Glandular capitate trichoms with an oval head (E), a rounded head (F). 

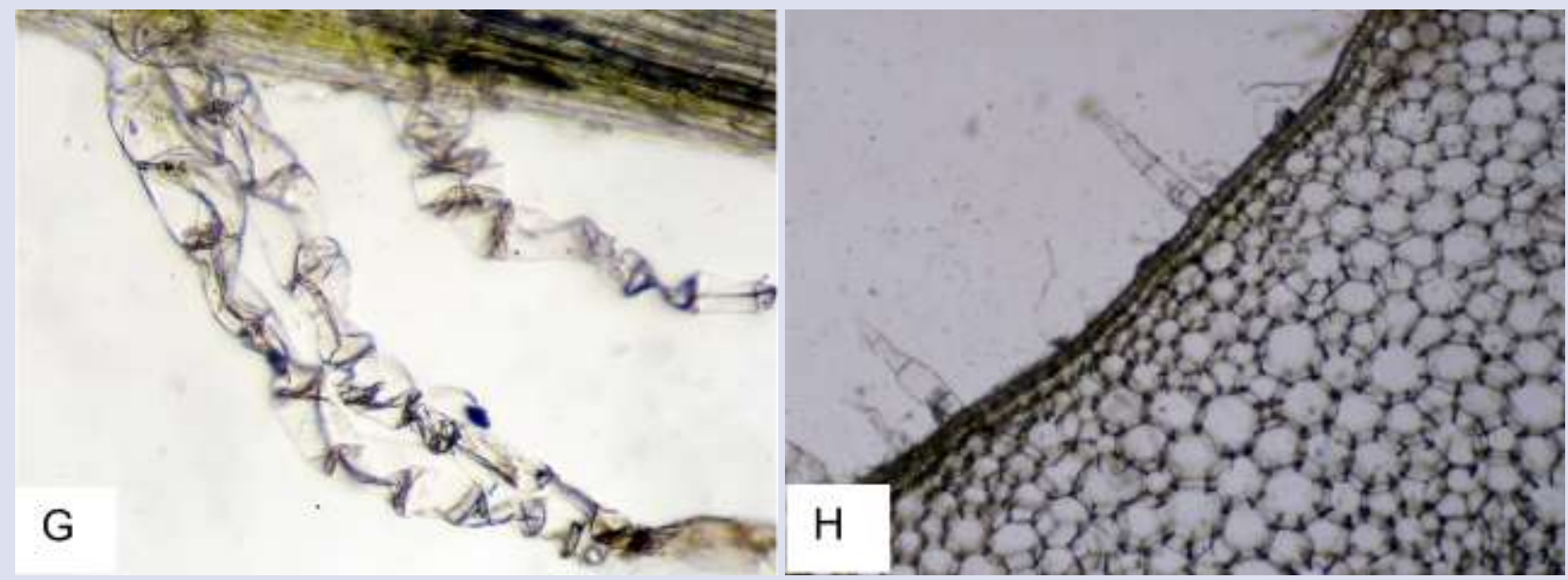

Figure 7: Photomicrograph of leaf petioles of Arctium lappa. Simple unbranched multicellular trichome (G). Cross section of the petiole. Epidermis (H); simple multicellular unbranched trichoms with thin and thick walls (I).
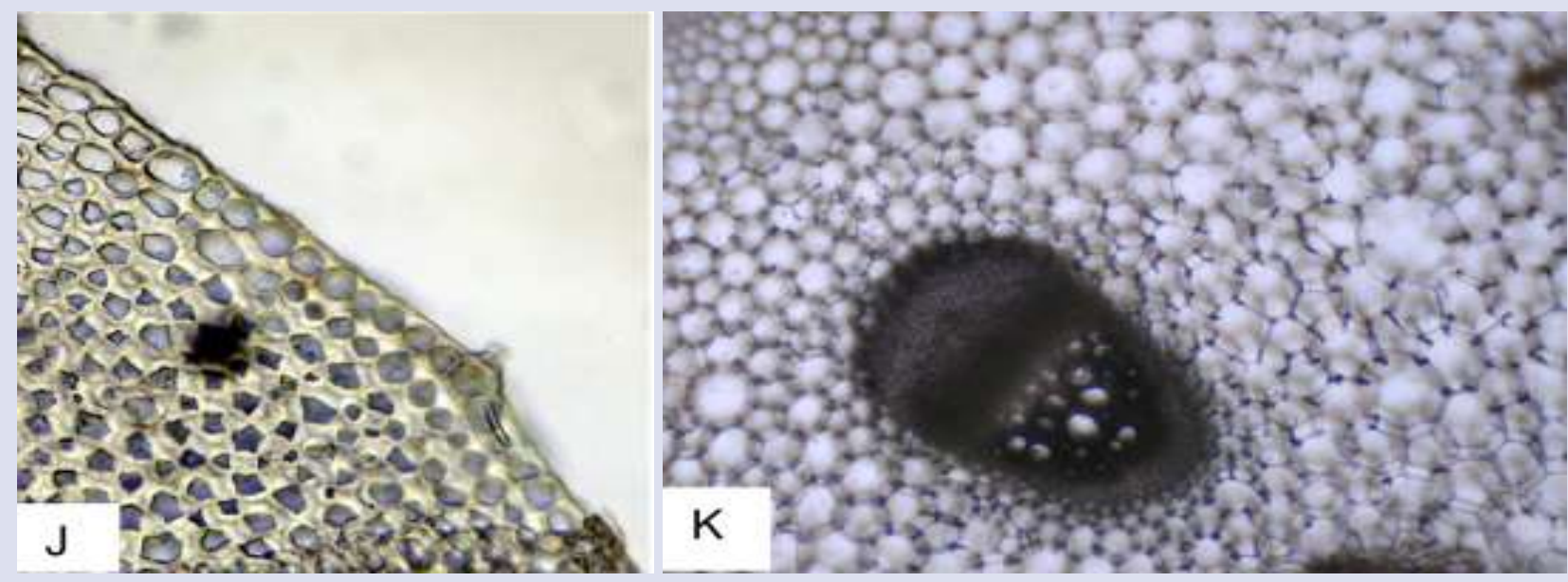

Figure 8: Photomicrograph of leaf petioles of Arctium lappa. Collenchyma (J), bicollateral open conducting bundle (K).
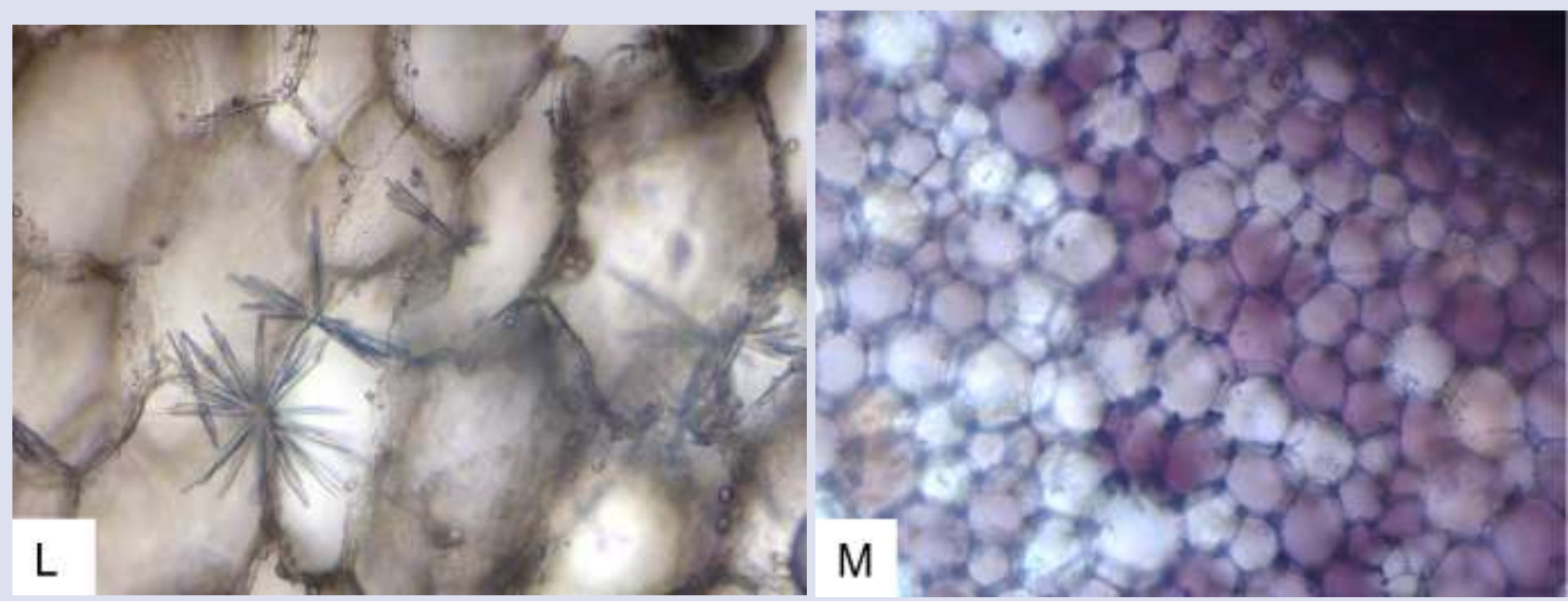

Figure 9: Photomicrograph of leaf petioles of Arctium lappa. Inulin spherocrystals (L); cells containing mucus (M). 

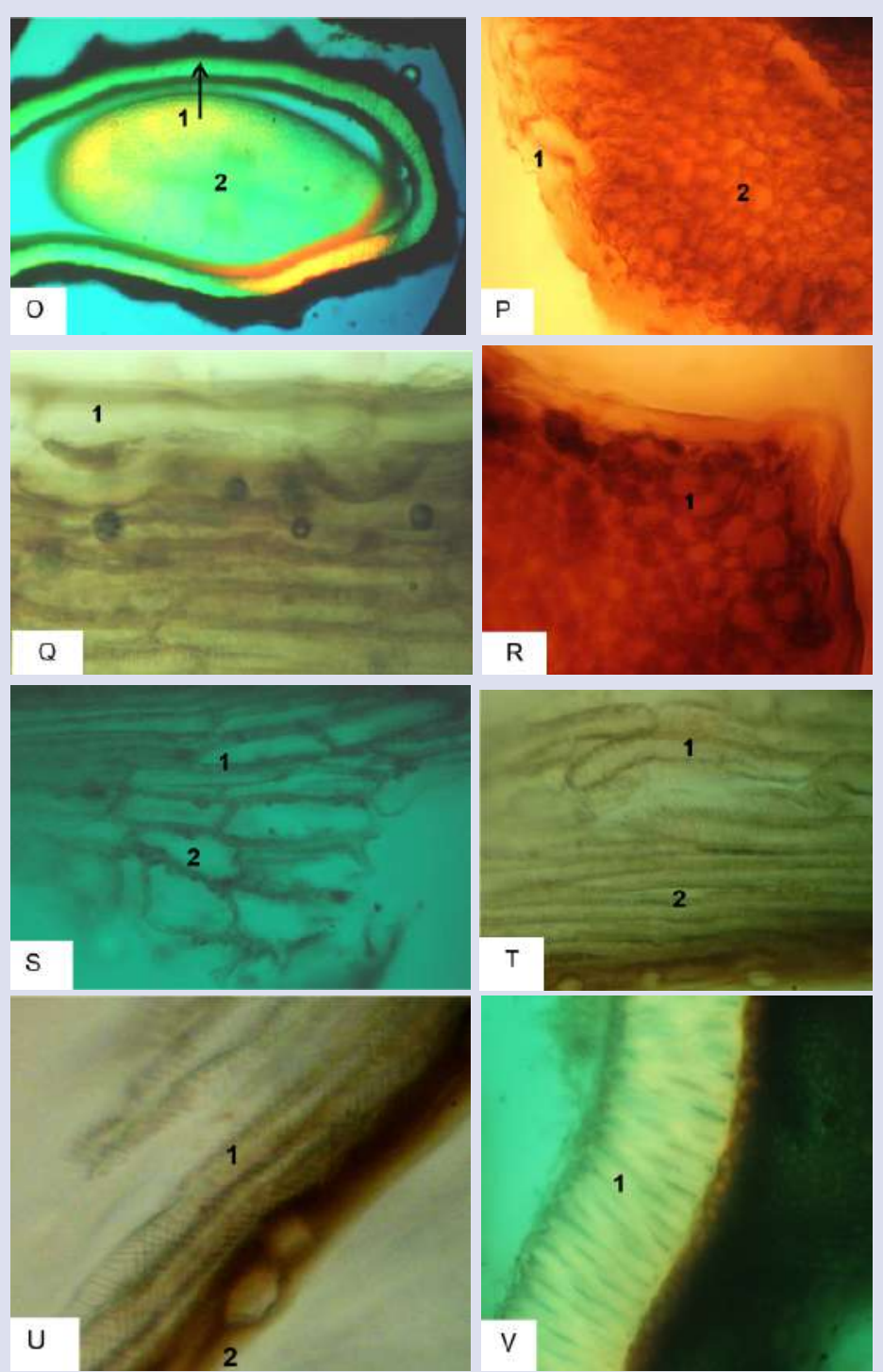

U

2

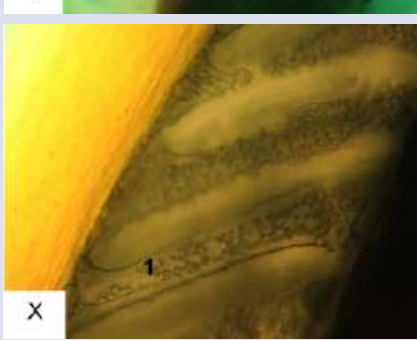

W
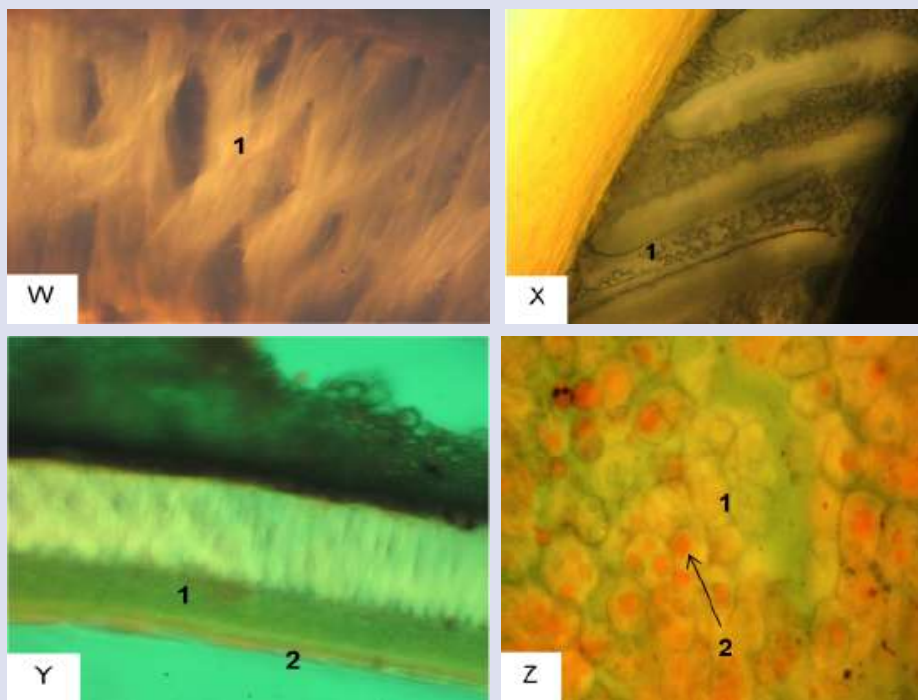

Figure 10: Fructus of Arctium lappa (x 420): cross section of achene (O): pericarp (1), cotyledons (2); cross section mesocarp (rib, P): brachysclereids (1), and macrosclereids,; longitudinal section of the pericarp (Q): exocarp (1); cross section pericarp (R): exocarp (1), mesocarp (2); longitudinal section mesocarp (S): macrosclereids (1), brachysclereids (2); longitudinal section mesocarp (T): macrosclereids (1), sclerenchymal fibers (2); longitudinal section of the pericarp (U): sclerenchymal fibers with reticular and spiral wall thickenings (1), endocarp (2); cross section of the seed coat (V): macrosclereids with strongly thickened walls (1); longitudinal section of the seed coat (W): macrosclereids with strongly thickened walls (1); longitudinal section of the seed coat (X): lignified macrosclereid wall with simple pores (1); cross section of achene $(Y)$ : inner layer of the seed coat with collapsed parenchymal cells (1); endosperm cell layer (2); cross section of the embryo cotyledons (Z): round or oval cells with aleurone grains and drops of fatty oil (1), drops of fatty oil (2). 
ethanol soluble extractive value, water soluble extractive value and moisture content as presented in Table 5 .

\section{DISCUSSION}

The phytochemical analysis of the extract and fractions revealed the presence of such groups of biologically active substances (BAS) as flavonoids, phenolic acids, tannins, polysaccharides, saponins, terpenoids (Table 1) which confirms the data given in the topic-related sources on chemical composition of burdock. ${ }^{56-60}$ The predominant group in leaves and fructus are phenolic compounds (flavonoids, phenolic acids, tannins), polysaccharides. The BAS components dominating in different parts of big burdock ensure in pharmacological effect of this species. ${ }^{44,56,58,59}$ As a result of microscopic examination it was found that in the leaves such group as anthocyanins is present. The maximum absorption in the visible area of the spectrum of the acidified aqueous extract of the leaf petiole is well pronounced, it is located in the long-wavelength region of the spectrum, where only coloured compounds are absorbed in the wavelength range peculiar for individual anthocyanins. ${ }^{60}$ The obtained data on phytochemical analysis will be used in the development of methods for analytical standardization of leaves and fructus, which will be reported in our next research.

The carried out histochemical reactions confirmed the presence of inulin in the leaf petioles; mucus in the leaves; essential oil; fatty oil and lignin in the seeds.

The pharmacognostic research has shown that the fructus and leaves of burdock have a set of unique diagnostic features (macroscopic, microscopic features, analytical characteristics). Organoleptic properties such as smell, taste and color were also established. It was found that the leaves are green on the outer surface and grayish pubescent on the inner surface; the fructus are brown with spots, sometimes black or mottled with black spots on a gray background; the roots are brown on the outer surface; the leaves, roots and fructus are most often odorless or with a faint smell, bitter, and the fruits have a slightly bitter or oily taste.

In accordance with macroscopic standards, macroscopic characteristics of the leaves such as edge, venation, base, apex, etc. - denticular, reticulated, bilateral and sharp; for fructus - shape, size, surface, presence of pericarp, number of seeds were specified.

The quantitative microscopy is not currently provided for in the Russian quality standards. But due to the trend of alignment of domestic standards with foreign ones, new quality indicators for raw materials, substances, and drugs will gradually be introduced into future editions of Russian pharmacopoeias. Therefore, in the given research the following quantitative indicators were specified for the leaves of big burdock: stomatal index and the number of stomata. It is worth mentioning that it is extremely difficult to detect stomata on the lower side of the leaf due to the large number of trichomes, so these indicators are determined only for the upper side of the leaf. Due to the fact that our studies previously established a link between man-made pollution and an increase in the number of glandular hairs on the example of plantain leaves, ${ }^{61}$ the number of glandular capitate trichomes, as well as essential oil glands on the upper and lower sides of the burdock leaf was additionally calculated. Comparative data on the number of trichomes in samples collected from ecologically clean and polluted territories will be revealed in one of the upcoming publications.

The description of microscopic features in the Russian quality standards differs from the European ones in the abundance of details of diagnostic features that allow distinguishing raw materials approved for utilization from morphologically and systematically similar plant species.

The detailed qualitative microscopic study of the big burdock leaves is performed and published for the first time. Large, oval, anomocytic stomata both submerged and not submerged in the epidermis were found. Epidermal cells are straight-walled, weakly branched, strongly branched with thin walls. The number of stomata depends on the height of the leaf growth. With an increase in leaves tiering the number of stomata detected in the objective field of view of the microscope lens decreases. It is also worth noting that it is extremely difficult to detect stomata on the underside of the leaves of any tier due to the large number of trichomes.

Several types of trichomes are found on the upper and lower sides of the leaves: simple multicellular unbranched hairs consisting of a base with straight-walled cells with thin 2-7 (more often 4) and thick (2-6) walls, the end cell of these hairs is long, narrow, cord-shaped, often strongly sinuous; glandular capitate trichomes with a single-celled rounded, less often oval head and a multicellular leg of cells (3-7, more often 3 cells) with straight and thin walls. The hair's head can have a brown-yellow filling.

In the micro-preparation of the leaf, essential oil glands which consist of 6-10 (more often 8) excretory cells arranged in 2 rows and 3-5 (more often 4) rows were discovered. This differs from the structure of the glands described in the topic-related sources as "peculiar for the Asteraceae family" and consisting of 4-6 excretory cells arranged in 3-4 rows. The microscopic examination of the petiole revealed a large number of simple multicellular hairs on the outside of the petiole consisting of a base with straight-walled cells with thin and thick walls, with a long, cord-shaped, often strongly sinuous end cell (as on the leaves). On the outer side there are straight- and thick-walled rectangular epidermis cells which are arranged in one row. The angular collenchyma is found in the ribs. The parenchyma is represented by small straight - and thin-walled polygonal cells or large straightand thick-walled cells of a rounded shape. The bicollateral bundles consisting of primary and secondary phloem, xylem and cambium are arranged cylindrically. In the central parts and parts closer to the leaf, a hollow core is found.

The detailed microscopy of the fructus, as well as the leaves, has not been previously performed in the topic-related sources. On the crosssection of the achene the pericarp and the seed are visible. The epidermis of the pericarp (exocarp) consists of palisade-like elongated cells with strongly thickened outer and side walls. The mesocarp of the achene consists of brachysclereids, macrosclereids and sclerenchymal fibers with latticed and spiral thickenings of cells. Brachy- and macrosclereids are located in the outer part of the mesocarp, and sclerenchymal fibers are located in the inner part. The endocarp consists of a single layer of oval cells without intercellular space, tightly fused with the cells of the seed shell. The seed shell is represented on the outside by a thick layer of macrosclereids with strongly thickened walls. The inner layer of the seed shell is represented by meshed parenchymal cells. The endosperm consists of a single layer of polygonal cells filled with aleurone grains and drops of fatty oil. The cotyledons of the plant embryo consist of round or oval-shaped cells containing aleurone grains and drops of fatty oil.

In Russian pharmacopoeias, as well as in foreign ones, the indicators of total ash and ash insoluble in hydrochloric acid are specified. The total ash in the leaves is $10.6-12.7 \%$, in the fructus $-3.73-6.33 \%$. This indicator provides useful information about the quality level, environmental cleanliness and appearance of plant raw materials. Acid-insoluble ash is more reliable than the total value of the total ash. Its content is 3.01$4.74 \%$ in the leaves, $0.12-0.89 \%$ in the fructus which indicates that oxalates and calcium carbonates dissolved in hydrochloric acid.

The "extractive value" indicator is used as one of quality indicators of unrefined herbal medicines in which individual components or groups of biologically active substances are difficult to evaluate by other methods. The results revealed that water-soluble substances dominate 
in the leaves and roots, their content is at the level of $21.1-26.4 \%$ in the leaves and at the level of $35.8-65.1 \%$ in the roots. Due to the specifics of the chemical composition of the seeds the content of substances soluble in ethanol was evaluated in the fructus. The content of these substances is $15.7-19.4 \%$. The moisture content is $4.1-11.7 \%$ for fructus, and $5.3-$ $11.9 \%$ for leaves at room temperature.

\section{CONCLUSION}

The results presented in this research can serve as a valuable source of information on diagnostic parameters for efficient identification of raw materials, development of suitable methods for chemical identification of leaves and fructus in the current and future studies.

\section{ACKNOWLEDGMENT}

The authors wish to acknowledge Department of Pharmaceutical Analysis of Siberian State Medical University, Department of Pharmacy of Kemerovo State Medical University, LLC «Visterra», Office of the State Employment Service in the Kirov region for research work (premises, reagents, equipment, plant materials).

\section{SOURCES OF FUNDING}

Self.

\section{CONFLICTS OF INTEREST}

We declare that we have no conflicts of interest.

\section{REFERENCES}

1. Arctium. The plant list. Version 1.1 Available from: http://www. theplantlist.org/1.1/browse/A/Compositae/Arctium/

2. Plant resources of the USSR: Flowering plants, their chemical composition, use. Family Asteraceae (Compositae). St. Petersburg; 1993.

3. Reshetnyak V, Tsigura IV. Herbalist. Kharkov; 1992.

4. Popov A.P. Herbal medicine book by Alexey Popov. Kemerovo, 1993.

5. Zimin VN. A professional reference book of a phytotherapist. St.Petersburg, 2003.

6. Makhlayuk VP. Medicinal plants in folk medicine. Moscow, 1992.

7. Lager' AA. Plant treatment. Phytotherapy. Krasnoyarsk, 1992.

8. Pashinskiy VG. Plants in therapy and disease prevention. Tomsk, 1989.

9. Korepanov CB. Plants in the prevention and treatment of cancer. Barnaul, 1999.

10. Nikolayev V. Farmatsevticheskiy vestnik. 1997;21:10-11.

11. State Pharmacopoeia of the Russian Federation XIV edition. Available from: http://resource.rucml.ru/feml/pharmacopia/14_4/ HTML/index.html

12. The Japanese Pharmacopoeia XVII edition. 2016. Available from: https://www.pmda.go.jp/english/rs-sb-std/standards-development/ jp/0019.html

13. Pharmacopee Francaise. X edition, 6 supplement: Monographies de souches pour preparations homeopathiques. Paris, 1989.

14. Kerasheva SI, Shershneva OK., Turetskova VF, Kerasheva SI. Lekarstvennyye rasteniya Altayskogo kraya. Tomsk, p. 131; 1986.

15. Tang $Y$, Lou Z, Yang L, Wang H. Screening of antimicrobial compounds against Salmonellaty phimurium from burdock (Arctium lappa) leaf based on metabolomics. European Food Research and Technology. 2015;240:1203-1209. doi: 10.1007/s00217-015-2423-0
16. Pereira J, Bergamo D, Pereira J. Antimicrobial activity of Arctium lappa constituents against microorganisms commonly found in endodontic infections. Braz Dent J. 2005;16 (3):192-196. doi:10.1590/s0103-644020050000300004

17. Gentil M, Pereira JV, Sousa YT. In vitro evaluation of the antibacterial activity of Arctium lappa as a phytotherapeutic agent used in intracanal dressings. Phytother Res. 2006;20(3): 184-186. doi: 10.1016/j.foodcont.2006.04.002

18. Holetz FB, Pessini GL, Sanches NR. Screening of some plants used in the Brazilian folk medicine for the treatment of infectious diseases. Mem Inst Oswaldo Cruz. 2002; 97(7):1027-1031. doi:10.1590/s0074-02762002000700017.

19. Patent 2689011 (FR). Treatment of herpes infection with composition containing quaternary ammonium compound and an anti-viral agent. E. Skrzypczak, 1993. Available from: https://patents. google.com/patent/US6284289B1/en

20. Matsumoto T, Hosono-Nishiyama K, Yamada H. Antiproliferative and Apoptotic Effects of Butyrolactone Lignans from Arctium lappa on Leukemic. Planta Med. 2006;72:276-278. doi:10.1055/s-2005-916174

21. Awale S, Lu J, Kalauni SK, Kurashima Y, Tezuka Y, Kadota S, Esumi $\mathrm{H}$. Identification of arctigenin as an antitumor agent having the ability to eliminate the tolerance of cancer cells to nutrient starvation. Cancer Res. 2006:66:1751-1757. doi: 10.1158/00085472.CAN-05-3143

22. Sak K, Jürisoo K. Estonian folk traditional experiences on natural anticancer remedies: From past to the future. Ain Raal. 2014:855866. doi:10.3109/13880209.2013.871641

23. Ito $Y$, Maeda S, Sugiyama T. Suppression of 7,12-dimethylbenz[a] anthracene-induced chromosome aberrations in rat bone marrow cells by vegetable juices. Mutation Research. 1986;172: 55-60.

24. Koshimizu K, Ohigashi H, Tokuda H. Screening of edible plants against possible anti-tumor promoting activity. Cancer Letters. 1988. Vol. 39. Pp. 247-257. doi: 10.1016/0304-3835(88)90067-5.

25. Morita K, Kada T, Namiki M. A desmutagenic factor isolated from burdock (Arctium lappa Linne). Mutat Res. 1984;129:25-31. doi: 10.1016/0027-5107(84)90119-2

26. Kim S, Kim J. Induction of anticarcinogenic ensyme by some Korean vegetable extracts. FASEB Journal.1997;3:369. doi: 10.1097/00008469-199403030-00007

27. Sato A. Studies on anti-tumor activity of crude drugs. I. The effects of aqueous extracts of some crude drugs in short-term screening test. Yakugaku Zasshi. 1989;109:407-423. doi:10.1248/ yakushi1947.109.6_407

28. Yersakhanova BK, Nurmukhambetov ZhN, Shabdarbayeva DM, Dauletzharova AK, Zhetpisbayev BA. Secondary immune deficience and its correction with Arcticum lappa and Plantago. Int $\mathrm{J}$ Immunorehabil. 1999; 12:125.

29. Maghsoumi-Norouzabad L, Alipoor B, Abed R, Sadat BE, MesgariAbbasi M, Jafarabadi MA. Effects of Arctium Lappa L. (Burdock) Root Tea on inflammatory status and oxidative stess in patients with knee osteoarthritis. Int J Rheum Dis. 2016;19(3):255-261. doi:10.1111/1756-185X.12477

30. Lin SC, Chung TC, Lin CC, Ueng TH, Lin YH, Lin SY, Wang LY. Hepatoprotective effects of Arctium lappa on carbon tetrachlorideand acetaminophen-induced liver damage. Am J Chin Med. 2000;28(2):163-173.doi: 10.1142/S0192415X00000210.

31. Carlotto J, de Souza LM, Baggio CH, de P Werner MF, MariaFerreira D, Sassaki GL, et al. Polysaccharides From Arctium Lappa L.: Chemical Structure and Biological Activity. Int J Biol Macromol. 2016;91:954-960. doi: 10.1016/j.ijbiomac.2016.06.033

32. Carlotto J, da Silva LM, Dartora N, Maria-Ferreira D, de A Sabry D, Filho APS, et al. Identification of a dicaffeoylquinic acid isomer from Arctium lappa with a potent anti-ulcer activity. Talanta. 2015;135:50-57. doi: 10.1016/j.talanta.2014.11.068 
33. Annunziata G, Barrea L, Ciampaglia R. Arctium lappa contributes to the management of type 2 diabetes mellitus by regulating glucose homeostasis and improving oxidative stress: A critical review of in vitro and in vivo animal-based studies. Phytotherapy Research. 2019;33(9):2213-2220. doi: 10.1002/ptr.6416

34. Silver A, Krantz J. The Effect of the Ingestion of Burdock Root on Normal and Diabetic Individuals. Annals of Internal Medicine. 1931;5:274-284. doi: doi.org/10.7326/0003-4819-5-3-274

35. Annunziata G, Barrea L, Ciampaglia R. Arctium lappa contributes to the management of type 2 diabetes mellitus by regulating glucose homeostasis and improving oxidative stress: A critical review of in vitro and in vivo animal-based studies. Phytotherapy Research. 2019;33(9):2213-2220. doi: 10.1002/ptr.6416

36. Chan Y-S, Cheng L-N, Wu J-H, Chan E, Kwan Y-W, Lee SM-Y, Leung GP-H, Yu PH-F, Chan S-W. A Review of the Pharmacological Effects of Arctium Lappa (Burdock). Inflammopharmacology Actions. 2011; 19(5):245-54. doi: 10.1007/s10787-010-0062-4

37. Li X, Zhao Z, Kuang P. Regulation of lipid metabolism in diabetic rats by Arctium lappa L. polysaccharide through the PKC/NF-KB pathway. Int J of Biol Macromolecules. 2019;136:115-122. doi: 10.1016/j.ijbiomac.2019.06.057

38. Kee Ji-Y, Hong S-H. Inhibition of Mast Cell-Mediated Allergic Responses by Arctii Fructus Extracts and Its Main Compound Arctigenin. J Agric Food Chem.2017;65:9443-9452. doi: 10.1021/ acs.jafc. $7 b 02965$

39. Hyam SR, Lee IA, Gu W, Kim KA, Jeong JJ, Jang SE, Kim DH. Arctigenin ameliorates inflammation in vitro and in vivo by inhibiting the PI3K/AKT pathway and polarizing M1 macrophages to M2-like macrophages. European J of pharmacology. 2013;708(1-3):21-29. doi: 10.1016/j.ejphar.2013.01.014

40. Gun G. Therapeutic value of Arctium lappa Linn. A review. Asian $J$ of Pharm and Clin Res.2019;12(7): 53-59. doi: 10.22159/ajpcr.2019. v12i7.33870

41. Maghsoumi-Norouzabad L, Alipoor B, Abed R, Sadat BE, MesgariAbbasi M, Jafarabadi MA. Effects of Arctium lappa L. (Burdock) root tea on inflammatory status and oxidative stress in patients with knee osteoarthritis. Int J Rheum Dis. 2016;19(3):255-261. doi: 10.1111/1756-185X.12477

42. Dias MM, Zuza O, Riani LR, de Faria Pinto P, Silva Pinto PL, Silva MP, et al. A In Vitro Schistosomicidal and Antiviral Activities of Arctium Lappa L. (Asteraceae) Against Schistosoma Mansoni and Herpes Simplex virus-1. Biomed Pharmacother. 2017;94:489-498. doi:10.1016/j.biopha.2017.07.116.

43. Yoo J-M, Yang JH, Yang HJ, Cho W-K, Ma JY. Inhibitory Effect of Fermented Arctium Lappa Fruit Extract on the IgE-mediated Allergic Response in RBL2H3 Cells. Int J Mol Med. 2016;37(2):501-518. doi: 10.3892/ijmm.2015.2447

44. Chan Y-S, Cheng L-N, Wu J-H, Chan E, Kwan Y-W, Lee SM-Y, et al. A Review of the Pharmacological Effects of Arctium Lappa (Burdock). Inflammopharmacology Actions. 2011; 19(5): 245-254. doi: 10.1007/s10787-010-0062-4

45. He Y, Fan Q, Cai T. Molecular mechanisms of the action of Arctigenin in cancer. Biomedicine \& Pharmacotherapy. 2018; 108:403-407. doi:10.1016/j.biopha.2018.08.158

46. Moritani S, Nomura M, Takeda Y, Miyamoto K. Cytotoxic components of bardanae fructus (Goboshi). Biol and Pharm Bull. 1996;11:1515-1517. doi:10.1248/bpb.19.1515
47. Hirose M, Yamaguchi T, Lin C. Effects of arctiin on PhIP-induced mammary, colon and pancreatic carcinogenesis in female SpragueDawley rats and MelQx-induced hepatocarcinogenesis in male F344 rats. Cancer Lett. 2000; 155:79-88. doi: 10.1016/s03043835(00)00411-0

48. Awale S, Lu J, Kalauni SK. Identification of arctigenin as an antitumor agent having the ability to eliminate the tolerance of cancer cells to nutrient starvation. Cancer Res. 2006;66:17511757. doi: $10.1158 / 0008-5472$

49. Umehara K, Nakamura M, Miyase T. Studies on differentiation inducers. VI. Lignan derivatives from Arctium fructus. Chem Pharm Bull. 1996;44:2300-2304. doi: 10.1248/cpb.44.2300

50. Xie L, Ahn E, Akao T. Transformation of arctiin to estrogenic and antiestrogenic substances by human intestinal bacteria. Chem Pharm Bull. 2003;51:378-384. doi: 10.1248/cpb.51.378

51. Cho MK, Jang YP, Kim YC, Kim SG. Arctigenin, a phenylpropanoid dibenzylbutyrolactone lignan, inhibits MAP kinases and AP-1 activation via potent MKK inhibition: the role in TNF-alpha inhibition. Int Immunopharmacol. 2004; 4:1419-1429. doi: 10.1007/s12272 010-0619-1

52. Knott A, Reuschlein K, Mielke H, Wensorra U, Mummert C, Koop $U$, et al. Natural Arctium lappa fruit extract improves the clinical signs of aging skin. J Cosmet Dermatol. 2008;7(4):281-289. doi: 10.1111/j.1473-2165.2008.00407.x

53. Miglani A, Manchanda RK. Observation study of Arctium lappa in the treatment of acne vulgaris. Homeopathy.2014;103(3):203-207. doi: 10.1016/j.homp.2013.12.002

54. Evans WC. Trease and Evans Pharmacognosy. IE.16ed. Maryland Heights, MO: Saunders; 2009.

55. European Pharmacopoeia 9th Edition. Available from: https://www. edqm.eu/en/news/shutdown-european-pharmacopoeia-9th-edition

56. Kolomiets NE, Boev RS, Zhalnina LV, Tikhomirova VA, Kashapov DR, Bondarchuk RA, et al. Chemical composition and biological activity of metabolites of the genus Arctium L. Khimiya Rastitel'nogo Syr'ya. 2021;2:29-57. doi: 10.14258/jcprm.2021028315

57. Wang HY, Yang JS, Pao YH. Studies on the chemical constituents of Arctium lappa L. Acta Pharmaceutica Sinica. 1993;28:911-917.

58. Al-Snafi AE. The Pharmacological Importance and Chemical Constituents of Arctium Lappa. A Review. Int $J$ for Pharm Res Scholars. 2014;3(1):663-670.

59. Ferracane R, Graziani G, Gallo M, Fogliano V, Ritieni A. Metabolic profile of the bioactive compounds of burdock (Arctium lappa) seeds, roots and leaves. J of Pharm and Biomed Analysis. 2010;51(2):399-404. doi: 10.1016/j.jpba.2009.03.018

60. Wang D, Bădărau AS, Swamy MK, Shaw S, Maggi F, Everson da Silva L, López V, Wai Kan Yeung A, Mocan A, Atanasov AG. Arctium Species Secondary Metabolites Chemodiversity and Bioactivities. Fron Plant Sci. 2019. Available from: https://doi.org/10.3389/ fpls.2019.00834

61. Harborne JB, Williams CA. Anthocyanins and other flavonoids. Nat Prod Rep.2001;18(3):310-33. doi: 10.1039/b006257j.

62. Abramets NYu, Kolomiets NE. Variability of anatomical and morphological features of plants in conditions of technogenic pollution and their importance in determining the quality of medicinal raw materials. Materials of the VI International Scientific Conference dedicated to the 100th anniversary of the birth of Polozhiy AV "Problems of studying the vegetation cover of Siberia»; 2017, Tomsk State University, Russia. 2017. 


\section{GRAPHICAL ABSTRACT}

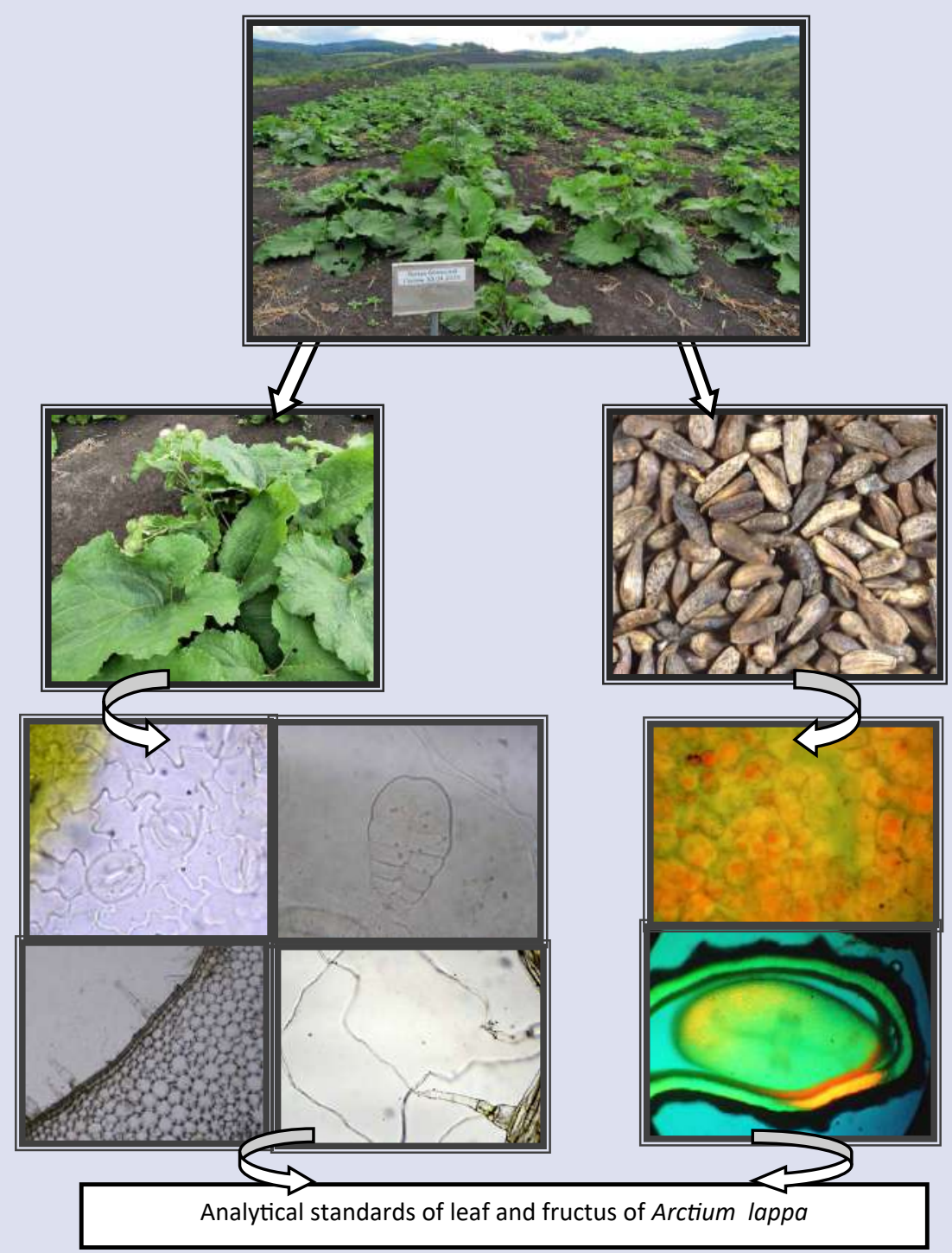

\section{ABOUT AUTHORS}

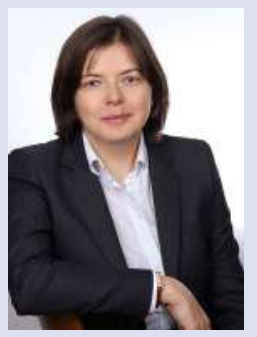

\section{KOLOMIETS, NATALIA EDUARDOVNA}

She is a Doctor of Pharmaceutical Sciences, Professor of the Department of Pharmaceutical Analysis of the Siberian State Medical University of the Ministry of Health of the Russian Federation, Professor of the Department of Pharmacy of the Kemerovo State Medical University of the Ministry of Health of the Russian Federation.

Her research interests include phytochemistry, natural product chemistry, drug evaluation and quality control, pharmacology.

E-ml: borkol47@mail.ru

Russia, Tomsk, Moskovsky trakt, 2 building 7, 634050, tel. 83822-901101 (ext. 1805).

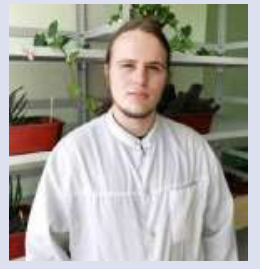

\section{KOROLEV, STEPAN ALEXANDROVICH}

He is a student of the Pharmaceutical faculty of the Siberian State Medical University of the Ministry of Health of the Russian Federation.

His research interests include phytochemistry, natural product chemistry.

E-ml: princ245@yandex.ru

Russia, Tomsk, Moskovsky trakt, 2 building 7, 634050, tel. 83822-901101 (ext. 1804). 

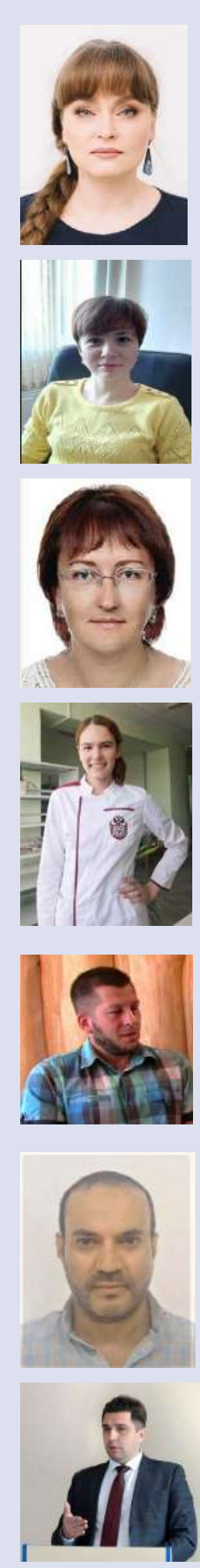

\section{ISAYKINA, NADEZHDA VALENTINOVNA}

She is an associate professor of the Department of Pharmaceutical Analysis of the Siberian State Medical University of the Ministry of Health of the Russian Federation.

Her research interests include natural product chemistry, drug evaluation and quality control.

E-ml: nadezhda.isaykina@gmail.com

Russia, Tomsk, Moskovsky trakt, 2 building 7, 634050, tel. 83822-901101 (ext. 1804).

\section{ZHALNINA, LUDMILA VLADIMIROVNA}

She is an Assistant of the Department of Pharmaceutical Analysis of the Siberian State Medical University of the Ministry of Health of the Russian Federation.

Her research interests include natural product chemistry, drug evaluation and quality control.

E-ml: zhalnina82@gmail.com

Russia, Tomsk, Moskovsky trakt, 2 building 7, 634050, tel. 83822-901101 (ext. 1804).

\section{ABRAMETS, NATALIA YURIEVNA}

She is a Senior Lecturer of the Department of Pharmaceutical Analysis, Siberian State Medical University of the Ministry of Health of the Russian Federation, Candidate of Pharmaceutical Sciences.

Her research interests include natural product chemistry, drug evaluation and quality control.

E-ml: abrameznu@mail.ru

Russia, Tomsk, Moskovsky trakt, 2 building 7, 634050, tel. 83822-901101 (ext. 1804).

\section{KUDRYAVTSEVA, DARIA VLADIMIROVNA}

She is a student of the Pharmaceutical faculty of the Siberian State Medical University of the Ministry of Health of the Russian Federation.

His research interests include phytochemistry, natural product chemistry.

E-ml: kudravcevadara037@gmail.com

Russia, Tomsk, Moskovskytrakt, 2 building 7, 634050, tel. 83822-901101 (ext. 1804).

\section{BOEV, ROMAN SERGEEVICH}

$\mathrm{He}$ is a director of science of the LLC "Visterra», candidate of Pharmaceutical Sciences.

His research interests include phytochemistry, natural product chemistry, high-level processing of different types of natural raw materials and producing of solid and dry extracts and therapeutic products on its base - products that have a positive physiological effect on the human body, contribute to the normalization of the functioning of organs and systems (gastrointestinal, cardiovascular, hepatobiliary, etc).

E-ml: brs-0@yandex.ru

Russia, Altayskoye village, Altai Krai, Zaozernaya str., 2, 659650.

\section{ALI, ABDUJALIL KAID HASAN}

$\mathrm{He}$ is a Postgraduate student of the Department of Pharmaceutical Analysis of the Siberian State Medical University of the Ministry of Health of the Russian Federation.

His research interests include phytochemistry, natural product chemistry.

E-ml: jalilalshemiry@yahoo.com

Russia, Tomsk, Moskovsky trakt, 2 building 7, 634050, tel. $83822-901101$ (ext. 1804).

\section{BONDARCHUK, RUSLAN ANATOLEVICH}

He is the head of the department of the State employment Service of the Kirov region, Candidate of Pharmaceutical Sciences.

His research interests include natural product chemistry, drug evaluation and quality control.

E-ml: bondarchuk686@mail.ru

Russia, Kirov, Rimma Yurovskaya str., 3, 610045.

Cite this article: Kolomiets NE, Korolev SA, Isaykina NV, Abramets NYr, Kudryavtseva DV, Boev RS, et al. Pharmacognostic Studies of the Leaves and Fructus of Arctium lappa L. (Asteraceae Bercht. \& J. Presl). Pharmacogn J. 2021;13(6)Suppl:.: 1734-1745. 